Situs Jurnal : $\underline{\text { http://ejurnal.stiepancasetia.ac.id/index.php/jieb }}$

Jilid 4 Nomor 1 Maret 2018

Hal $093-109$

\title{
ANALISIS COST OF GOOD SOLD DALAM MENENTUKAN HARGA JUAL BATU ANDESIT PADA PT. HARMAK INDONESIA YOGYAKARTA
}

\author{
Tina Lestari*
}

Abstract: This research's goal are to understand how to determination of cost of goods and to provide input on the determination of Cost of Good Sale at PT. Harmak Indonesia in Yogyakarta. The results of this analysis show that the Cost Of Good Sold, during this time, there is still allocation of cost experiencing confusion, because it is not confirmed by explanation of specific expenditure. There is difficulty in determining cost, so there are some cost that ultimately come in the form of overall estimation and aggregation. The Determination of cost of goods sold in addition to costs, the total inventory of andesit types is also part of the determinant because it is a divisor in determining outcome. The calculation of cost of goods sold is less precise and affects the value of costing of goods sold is quite significant. The determination of the selling price of andesite stone to ROM and SPLIT type by a company must have the determination of how much profit or margin to be obtained, so that the determination of the selling price must be above the cost of goods sold with added expected profit margin, such as profit margin 10\%, 20\% 30\% and so on as desired above (>) cost of goods sold ROM and SPLIT.

Keywords: Cost Of Good Sold, cost allocation, andesite stone, PT. Harmak Indonesia

Abstrak: Penelitian ini bertujuan untuk memahami bagaimana penetapan Harga pokok penjualan dan untuk memberikan masukan tentang penetapan Harga pokok penjualan PT. Harmak Indonesia di Yogyakarta. Hasil analisis menunjukkan bahwa Penetapan Harga pokok penjualan selama ini berjalan masih ada alokasi biaya yang mengalami kerancuan karena tidak dipertegas dengan penjelasan pengeluaran biaya secara spesifik sehingga mengalami kesulitan dalam penentuan biaya, sehingga ada beberapa biaya yang akhirnya berupa estimasi dan penggabungan secara keseluruhan. Penentuan harga pokok penjualan selain biaya-biaya, jumlah persediaan dari jenis batu andesit juga merupakan bagian dari penentu karena merupakan pembagi dalam menentukan hasil. Perhitungan harga pokok penjualan kurang tepat dan mempengaruhi nilai penetapan harga pokok penjualan yang cukup signifikan. Penentuan harga jual batu andesit untuk jenis ROM dan SPLIT oleh perusahaan haruslah memiliki ketetapan berapa keuntungan atau margin yang ingin diperoleh sehingga penentuan harga jual haruslah diatas dari harga pokok penjualan dengan ditambahkan dengan margin keuntungan yang diharapkan, seperti ketentuan margin keuntungan 10\%, 20\%, 30\% dan seterusnya sesuai dengan yang diinginkan diatas (>) harga pokok penjualan ROM dan SPLIT.

Kata kunci : Harga pokok penjualan, alokasi biaya, batu andesit, PT. Harmak Indonesia

\section{Latar Belakang}

Perkembangan tambang batu andesit cukup baik dalam dunia bisnis membuat perusahaan-perusahaan yang bergerak dibidang sama semakin meningkatkan persaingan. Persaingan merupakah hal yang wajar dalam hal menawarkan produk dengan kualitas dan harga 
yang akan menarik perhatian dan minat pembeli. Salah satu informasi yang diperlukan oleh manajemen adalah menentukan harga pokok penjualan (Cost Good Of Sold) dalam (istilah yang dipakai IAI) harga pokok penjualan (Cost Good Of Sold) adalah segala cost yang timbul dalam rangka membuat suatu produk menjadi siap untuk dijual. Atau dengan kalimat lain, Harga Pokok penjualan adalah cost yang terlibat dalam proses pembuatan barang atau yang bisa dihubungkan langsung dengan proses yang membawa barang dagangan siap untuk dijual.

Harga pokok penjualan (Cost Good Of Sold) dilakukan untuk memproyeksikan tingkat kemajuan perusahaan yang diharapkan dimasa mendatang, dimana juga sumber data untuk mengukur biaya, merencanakan dan mengendalikan serta untuk menganalisa biaya. Biaya yang terkait langusng dalam produksi dan penjualan batu andesit di lokasi pertambangan meliputi :

1. Biaya Lokasi Pertambangan

a. Biaya sewa alat berat, yaitu excavator dan breaker

b. Biaya bahan bakar alat berat

c. Biaya bahan bakar mesin

d. Operator

e. Biaya gaji karyawan yang berkaitan langsung dengan produksi (pekerja harian dan pekerja mingguan)

2. Biaya Umum dan administrasi

a. Biaya gaji dan tunjangan karyawan yang tidak berkaitan langsung dengan produksi.

b. Biaya Perbaikan dan pemeliharaan mesin

c. Biaya Peralatan

d. Biaya Administrasi Kantor

e. Biaya Utilities

f. Biaya Depresiasi untuk peralatan mesin dengn metode garis lurus

g. Biaya amortisasi izin penambangan yan akan di amortisasi akhir tahun keduapuluh adalah nol

h. Biaya retribusi atas pelaksanaan tabang

i. Biaya Corporate Socia Responsibility (CSR)

3. Pajak pendapatan yang ditentukan sesuai dengan peraturan undang-undang.

Secara umum biaya produksi dibagi menjadi tiga elemen yaitu biaya bahan baku, biaya tenaga kerja langsung dan biaya produksi lainnya (Biaya Overhead). Untuk pengumpulan biaya produksi ditentukan oleh karakteristik proses produksi yang dihasilkan perusahaan. Karakteristik kegiatan perusahaan menggunakan metode pengumpulan biaya produksi. Ada dua macam metode pengumpulan biaya produksi yaitu: metode harga pokok proses dan metode harga pokok pesanan. Untuk kepentingan perencanaan laba jangka pendek, manajemen memerlukan informasi biaya yang dipisahkan menurut perilaku biaya dalam hubungannya dengan perubahan volume kegiatan. Penentuan Harga pokok penjualan (Cost Good Of Sold) adalah persedaan awal diambahkan dengan pembelian bersih dikurangi persediaan akhir, dimana perhitungan Harga Pokok Penjualan dapat dirumuskan dengan:

HPP = Inventory Usage + Direct Labour Cost + Overhead Cost

Inventory Usage dapat kita turunkan menjadi :

Saldo Awal(+)Pembelian atau Penambahan(-)Saldo Akhir dan pembelian Pembelian itu sendiri dapat kita turunkan menjadi: Purchase atau invoice (-) Discount (-) Return. 
PT. Harmak Indonesia adalah perusahaan yang bergerak dibidang manufaktur, yang memproduksi batu dengan beberapa jenis batu. Jenis - jenis batu yang dihasilkan :

1. ROM

2. Split

- Split Uk 1 x 2

- Split Uk 2 x 3

- Ciping

- Abu batu

PT. Harmak Indonesia berlokasi proyek didaerah Kabupaten Kulon Progo Daerah Istimewa Yogyakarta. Dalam hal ini Perusahaan sulit melakukan perhitungan Harga pokok penjualan (Cost Good Of Sold) dari produksinya yang terdiri dari beberapa jenis batu yang dihasilkan, Karena setiap jenis batu yang dihasilkan mempunyai harga jual berbeda dan sulit menentukan jenis batu mana yang sebenarnya memiliki keuntungan yang lebih besar. Menyadari pentingnya penentuan harga pokok penjualan secara wajar, oleh karena itu penulis tertarik untuk melakukan penelitian dan membahasnya dalam penelitian dengan objek PT. Harmak Indonesia Yogyakarta dengan judul: "Analisis Cost Of Good Sold (COGS) dalam Penentuan Harga Jual Batu Andesit pada PT. Harmak Indonesia Yogyakarta”.

Berdasarkan latar belakang penelitian yang telah diuraikan diatas maka masalah yang diteliti pada penelitian ini dirumuskan sebagai berikut :

1. Bagaimana penetapan Harga pokok penjualan (Cost Of Good Sold) pada PT. Harmak Indonesia Yogyakarta yang selama ini berjalan?

2. Bagaimana hasil analisis penetapan harga pokok penjualan (Cost Of Good Sold) yang seharusnya pada PT. Harmak Indonesia Yogyakarta?

\section{Kajian Literatur}

Pada dasarnya Harga Pokok Penjualan (istilah yang dipakai IAI) adalah segala cost yang timbul dalam rangka membuat suatu produk menjadi siap untuk dijual. Atau dengan kalimat lain, Harga Pokok penjualan adalah cost yang terlibat dalam proses pembuatan barang atau yang bisa dihubungkan langsung dengan proses yang membawa barang dagangan siap untuk dijual. truktur dasar harga pokok penjualan pada dasarnya terdiri dari dari 3 (tiga) elemen besar saja:

1. Persediaan (Inventory)

2. Tenaga Kerja Langsung (Direct Labor Cost)

3. Overhead Cost

Menurut Mulyadi (2010: 10) harga pokok merupakan pengorbanan sumber ekonomi untuk memperoleh aktiva, selain itu harga pokok juga digunakan untuk menunjukkan pengorbanan sumber ekonomi dalam pengolahan bahan baku menjadi produk. Namun karena pembuatan produk tersebut bertujuan mengubah aktiva (berupa persediaan bahan baku) menjadi aktiva lain (persediaan produk jadi), maka pengorbanan bahan baku tersebut, yang berupa biaya bahan baku, akan membentuk harga pokok produksi.

Setiap perusahaan yang dilakukan penghitungan harga pokok produk mempunyai tujuan yang ingin dicapainya. Adapun tujuan dari penghitungan harga pokok produk adalah:

1. Untuk memberikan bantuan guna mendekati harga yang dapat dicapai.

2. Untuk menilai harga-harga yang dapat dicapai atau ditawarkan dari pendirian ekonomi perusahaan itu sendiri.

3. Untuk menilai penghematan dari proses produksi. 
4. Untuk menilai barang yang masih dikerjakan.

5. Untuk penetapan yang terus-menerus dan anlisis dari hasil perusahaan.

Terdapat serangkaian metode yang dapat digunakan untuk Pengumpulan Harga Pokok Produksi, meliputi:

1. Metode harga pokok pesanan (job order costing) adalah metode dengan menggunakan Sistem job order costing digunakan untuk perusahaan yang memproduksi bermacam produk selama periode tertentu. Sebagai contoh: perusahaan pakaian levis straus membuat pakaian jeans untuk pria dan wanita. Dalam sistem job order costing, biaya ditelusuri dan dialokasikan ke pekerjaan dan biaya untuk menyelesaikan pekerjaan tersebut dibagi dengan jumlah unit yang dihasilkan untuk menghasilkan harga rata-rata per unit. Karakteristik job order costing menurut Mulyadi (2010:15) adalah:

a. Digunakan jika perusahaan memproduksi berbagai macam produk sesuai dengan spesifikasi pemesan dan setiap jenis produk perlu dihitung harga pokoknya secara individual.

b. Biaya produksi harus dipisahkan menjadi dua golongan pokok: biaya produksi langsung dan biaya produksi tak langsung.

c. Biaya produksi langsung terdiri dari biaya bahan baku dan biaya tenaga kerja langsung, sedangkan biaya produksi tak langsung disebut dengan istilah biaya overhead pabrik.

d. Biaya produksi langsung diperhitungkan sebagai harga pokok pesanan tertentu berdasarkan biaya yang sesungguhnya terjadi, sedangkan biaya overhead pabrik diperhitungkan ke dalam harga pokok pesanan berdasarkan tarif yang ditentukan di muka.

e. Harga pokok per unit produk dihitung pada saat pesanan selesai diproduksi dengan cara membagi jumlah biaya produksi yang dikeluarkan untuk pesanan tersebut dengan jumlah unit produk yang dihasilkan dalam pesanan yang bersangkutan.

2. Metode harga pokok proses (process costing) merupakan sistem yang digunakan dalam perusahaan yang memproduksi satu jenis produk dalam jumlah besar dalam jangka panjang. Contohnya adalah produksi kertas. Prinsip dasar dari process costing adalah mengakumulasikan biaya dari operasi atau departemen tertentu selama satu periode penuh (bulanan, kuartalan dan tahunan) dan kemudian membaginya denganjumlah unit yang diproduksi selama periode tersebut. Karakteristik process costing menurut Mulyadi (2010:17) adalah:

a. Produk diolah secara massal dalam jumlah yang cukup besar dan sesuai dengan kapasitas produksi mesin-mesin yang ada.

b. Sifat produk yang diolah menunjukkan keseragaman antara produk yang satu dengan yang lainnya. Tingkat kesamaannya membutuhkan presisi yang tinggi sehingga sulit dibedakan antara produk yang satu dengan lainnya.

c. Produk diolah secara terus-menerus (continuous), sehingga antara periode yang satu dengan periode yang lain tidak dibatasi oleh jarak waktu tertentu (time lag). Tiadanya jarak waktu tersebut disebabkan penghentian suatu proses produksi yang ditujukan hanya untuk menghitung harga pokok produk menjadi tidak ekonomis, justru menimbulkan kerugian yang cukup berarti bagi perusahaan.

d. Laporan harga pokok produksi disusun atau dihitung secara periodik. Antara periode yang satu dengan yang lainnya harus ditetapkan batasan waktu tertentu (cut off).

e. Tujuan produksi tidak dimaksudkan untuk memenuhi permintaan khusus dari pelanggan tertentu. Produksinya dilaksanakan untuk mengisi gudang dengan mengingat permintaan pasar yang sudah diperkirakan terlebih dahulu untuk jangka waktu 
tertentu. Mengingat proses produksi tidak boleh dihentikan pada setiap saat (setup costnya sangat mahal) maka manajemen harus menganggarkan jumlah yang harus diproduksi dalam jumlah waktu tertentu.

Aliran Harga Pokok Pesanan

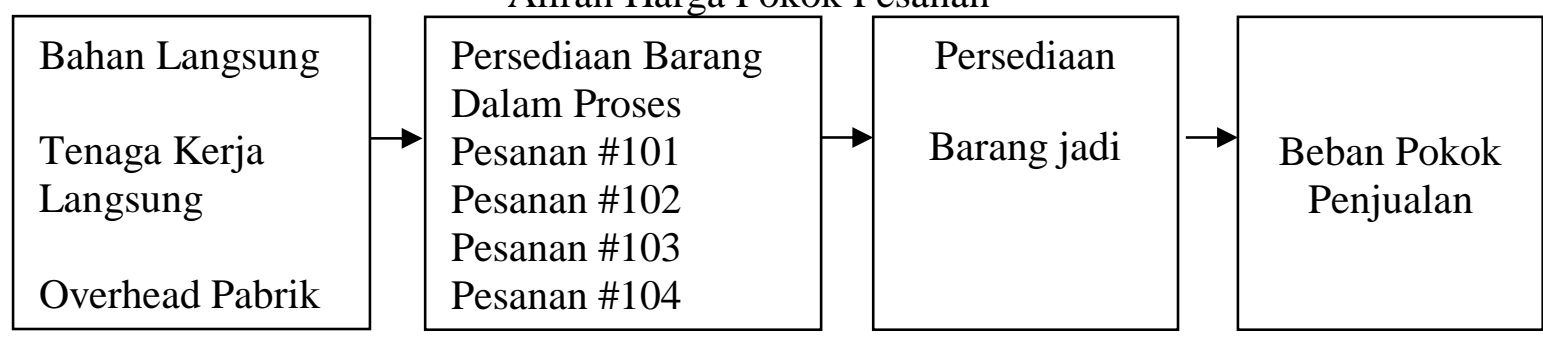

Aliran Harga Pokok Proses

\begin{tabular}{|l|} 
Bahan Langsung \\
Tenaga Kerja \\
Langsung \\
Overhead Pabrik
\end{tabular}$\rightarrow \begin{gathered}\text { Barang } \\
\text { Dalam Proses } \\
\text { Departemen } \\
\text { A }\end{gathered} \rightarrow \begin{gathered}\text { Barang } \\
\text { Dalam Proses } \\
\text { Departemen } \\
\text { B }\end{gathered} \rightarrow \underset{\begin{array}{c}\text { Persediaan } \\
\text { Barang } \\
\text { jadi }\end{array}}{\rightarrow} \rightarrow \begin{aligned} & \text { Beban } \\
& \text { Pokok } \\
& \text { Penjualan }\end{aligned}$

\section{Gambar 1. Aliran Biaya Dalam Sistem Harga Pokok Pesanan Dan Sistem Harga Pokok Proses Al}

Sumber : Haryono Jusup (2011:651)

Gambar 1 menunjukkan bagaimana aliran biaya dalam sistem Harga Pokok dijelaskan menurut Haryono Jusup. Sedangkan metode yang digunakan dalam Penentuan Harga Jual Mulyadi (2001:54) mengemukakan empat metode dalam penentuan harga jual yaitu :

1. Penentuan Harga Jual Normal (Normal Pricing) Dalam keadaan normal, manajer penentu harga jual memerlukan informasi biaya penuh untuk masa yang akan datang sebagai dasar penentuan harga jual produk atau jasa. Metode penentuan harga jual normal sering juga disebut dengan istilah cost plus pricing, Karena harga jual ditentukan dengan menambah biaya masa yang akan datang dengan suatu persentase mark up.

2. Penentuan Harga Jual Dalam Cost-Type Contract Cost-type contract adalah pembuatan produk atau jasa yang pihak pembeli setuju untuk membeli produk atau jasa pada harga yang didasarkan pada total biaya yang sesungguhnya dikeluarkan oleh produsen ditambah dengan laba yang dihitung sebesar persentase tertentu dari total biaya sesungguhnya tersebut. Jikadalam keadaan normal, harga jual produk atau jasa yang akan di jual dimasa yang akan datang di tentukan dengan metode cost-plus pricing berdasarkan taksiran biaya penuh sebagai dasar, dalam cost-plus contract harga jual yang dibebankan kepada konsumen dihitung berdasarkan biaya penuh sesungguhnya yang telah dikeluarkan untuk memproduksi dan memasarkan produk.

3. Penentuan Harga Jual Pesanan khususPesan khusus merupakan pesanan yang diterima oleh perusahan diluar pesanan regular perusahan.Biasanya konsumen yang melakukan pesanan khusus ini meminta harga dibawah harga normal, bahkan seringkali harga yang diminta oleh konsumen berada dibawah biaya penuh, karena biasanya dipesanan khusus mencakup jumlah yang besar. 
4. Penentuan Harga Jual Produk atau jasa yang dihasilkan oleh perusahaan yang diatur dengan perusahan pemerintahProduk dan jasa yang di hasilkan untuk memenuhi kebutuhan pokok masyarakat luas seperti listrik,air,telepon dan telegraf, transportasi dan jasa pos diatur dengan peraturan pemerintahHarga jual produk dan jasa tersebut detentukan berdasarkan biaya penuh masa yang akan datang ditambah dengan laba yang diharapkan.

Penelitian ini dilakukan atas dasar serangkaian penelitian-penelitian terdahulu. Melalui analisis yang lengkap terhadappenelitian-penelitian terdahulu, penelitian dapat membangun model konseptual untuk penelitian ini. Penelitian-penelitian terdahulu yang digunakan pada penelitian ini meliputi :

1. Andre Henri Slat (2013) penelitian mengenai : Analisis Harga Pokok Produk dengan metode full costing dan penentuan harga jual pada CV. Anugerah Genteng Manado , Tujuan penelitian ini adalah untuk mengevaluasi penentuan harga pokok produk dan penetapan harga jual yang dilakukan perusahaan, untuk dibandingkan dengan metode penentuan harga pokok proses dengan pendekatan full costing, dan metode penetapan harga jual berdasarkan cost plus pricing. Metode analisis yang digunakan dalam penelitian ini adalah metode analisis deskriptif.Hasil penelitian ini menunjukkan terdapat kelemahan dalam perhitungan harga pokokproduk perusahaan yaitu kalkulasi harga pokok produk yangdilakukan perusahaan lebih tinggi dari pada harga pokok produk menurut harga pokok produk setelah dievaluasi, menurut perusahaan harga pokok produk genteng garuda, sebesar Rp. 2.100, genteng KIA sebesar Rp. 2.000, paving serasi sebesar Rp. 1.400, paving 3 berlian sebesar Rp. 1.300, dan hollow brich sebesar Rp. 2.400. Sedangkan harga pokok produk setelah dievaluasi untuk genteng garuda sebesar Rp. 1.940, genteng KIA sebesar Rp. 1.864, paving serasi sebesar Rp. 1.334, paving 3 berlian sebesar Rp. 1.243, dan hollow brich sebesar Rp. 2.277, hal ini disebabkan karena perusahaan tidak membebankan biaya produksi yaitu biaya penyusutan gedung pabrik, biaya penyusutan mesin \& peralatan, dan biaya asuransi dalam perhitungan harga pokok produksi.

2. Bellinda Macpal, Jenny Morasa, Victorina Tirayoh (2014) Analisis perhitungan harga pokok penjualan barang produksi pada jeoara Meubel di Kota Bitung,tujuan penelitian tersebut, maka metode yang digunakan dalam penelitian adalah metode analisis deskriptif dengan mengambil data harga pokok penjualan dari data perusahaan, lalu mengambil landasanlandasan teori yang berhubungan dengan masalah yang diteliti, kemudian membandingkan kedua data tersebut. Setelah itu menganalisis langkah-langkah yang diambil perusahaan dalam perhitungan tersebut. Hasil penelitian ini menunjukkan bahwa perhitungan harga pokok penjualan pada jepara meubel belum dapat dikatakan efektif, disebabkan perusahaan belum memperhitungkan biaya non produksi, dimana biaya-biaya tersebut juga termasuk biaya yang dikeluarkan perusahan walaupun tidak termasuk dalam biaya produksi satu set kursi dan meja tamu. Terdapat perbedaan harga jual antara perusahan dan hasil setelah dievaluasi dengan metode full costing karena biaya non produksi diperhitungkan sesuai dengan rumus yang hasilnya lebih tinggi dari perusahaan. Diharapkan jepara meubel dapat meninjau kembali perhitungan harga pokok.

3. Reymon (2009) meneliti mengenai : Analisa penerapan harga jual dengan metode variable costing pada PT. Massindo Sinar Pratama Manado bahwa PT. Massindo Sinar Pratama didalam penerapan harga jual masih belum optimal dan sebaiknya menggunakan metode variable costing. Hal ini harus diusahakan agar laba yang diharapkan dapat dicapai dengan benar.

4. Trigono Utomo \& Christiono Utomo (2014) meneliti mengenai Penetapan harga pokok penjualan berdasarkanalokasi biaya terhadap posisi rumah pada perumahan Green Park Residence Sampang. Tujuan mengetahui harga pokok penjualan untuk setiap unit rumah 
berdasarkan alokasi biaya terhdap posisi rumah pada perumahan dan margin keuntungan yang ditetapkan. Untuk mendapatkan harga pokok penjualan yang berbeda-beda berdasarkan posisi rumah maka perlu dilakukan analisa alokasi biaya tetap. Analisa biaya dilakukan dengan menggunakan metode analisa titik impas. Dari hasil analisa yang dilakukan, didapatkan persamaan harga pokok penjualan rumah tipe 54/96 terhadap kenaikan prosentase margin keuntungan. Pada kelompok harga 1 didapatkan persamaan $\mathrm{Y}$ $=719.691,046 \mathrm{X}+262.209,447,206$, kelompok harga $2 \mathrm{Y}=686.392,595 \mathrm{X}+$ 257.972.820,629 , dan untuk kelompok harga 3 yaitu $=683.178,163 X+239.934 .886,053$ Dimana Y meripakan harga pokok penjualan (HPP) dan X adalah persentase margin keuntungan.

\section{Metode Penelitian}

Dalam penelitian ini peneliti mengambil data populasi dari Laporan PT. Harmak Indonesia Yogyakarta yang terdiri dari laporan perhitungan harga pokok penjualan, dengan detail data penjualan, data produksi, dan data biaya-biaya. Berdasarkan populasi data, peneliti mengambil sampel yang terdiri dari perhitungan harga pokok penjualan yang dilengkapi dengan detail data penjualan, produksi dan biaya-biaya yang dikeluarkan dalam periode Oktober sampai dengan Desember 2016. Berkaitan dengan permasalahan yang diangkat sehingga variabel perhitungan harga pokok penjualan yang dilengkapi dengan detail data penjualan, produksi dan biaya-biaya. Penelitian ini dilakukan untuk menganalisa Harga pokok penjualan (cost of good sold) terhadap harga jual batu andesit yang ditunjukan dengan data perhitungan selama ini, kemudian dianalisa mengenai alokasi biaya-biaya yang terjadi didalamnya apakah sudah sesuai berdasarkan alokasi biaya tetap, biaya variable untuk menentukan harga pokok penjualan batu andesit dengan rumusan perhitungan penentuan harga pokok penjualan (cost of good sold) seharusnya.

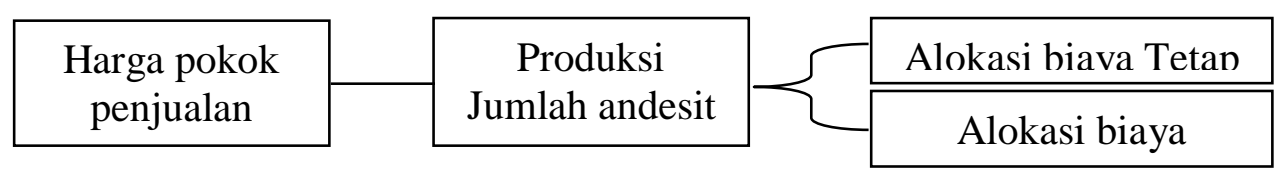

\section{Gambar 2. Skema Harga pokok penjualan}

Dimana pada akhirnya diperoleh gambaran jelas mengenai proses Analisis harga pokok penjualan (Cost of good sold) dalam menentukan harga jual batu andesit pada PT. Harmak Indonesia Yogyakarta, seperti ditunjukkan pada skema analisis penelitian ini pada Gambar 3.

\section{Hasil Penelitian dan Pembahasan}

PT. Harmak Indonesia adalah perusahaan swasta nasional yang bergerak di usaha pertambanga andesit di daerah Kulon Progo,Yogyakarta. PT. Harmak Indonesia memproduksi dan menjual andesit dalam bentuk raw material dan split dengan ukuran. Biaya - biaya produksi dan perhitungan harga pokok penjualan dari andesit untuk per meter kubik (cubic meters / CBM). Laporan penjualan PT. Hamark Indonesia dari Oktober sampai dengan Desember 2016 menunjukkan nilai penjualan yang terus meningkat, seperti ditampilkan pada Tabel 1. 


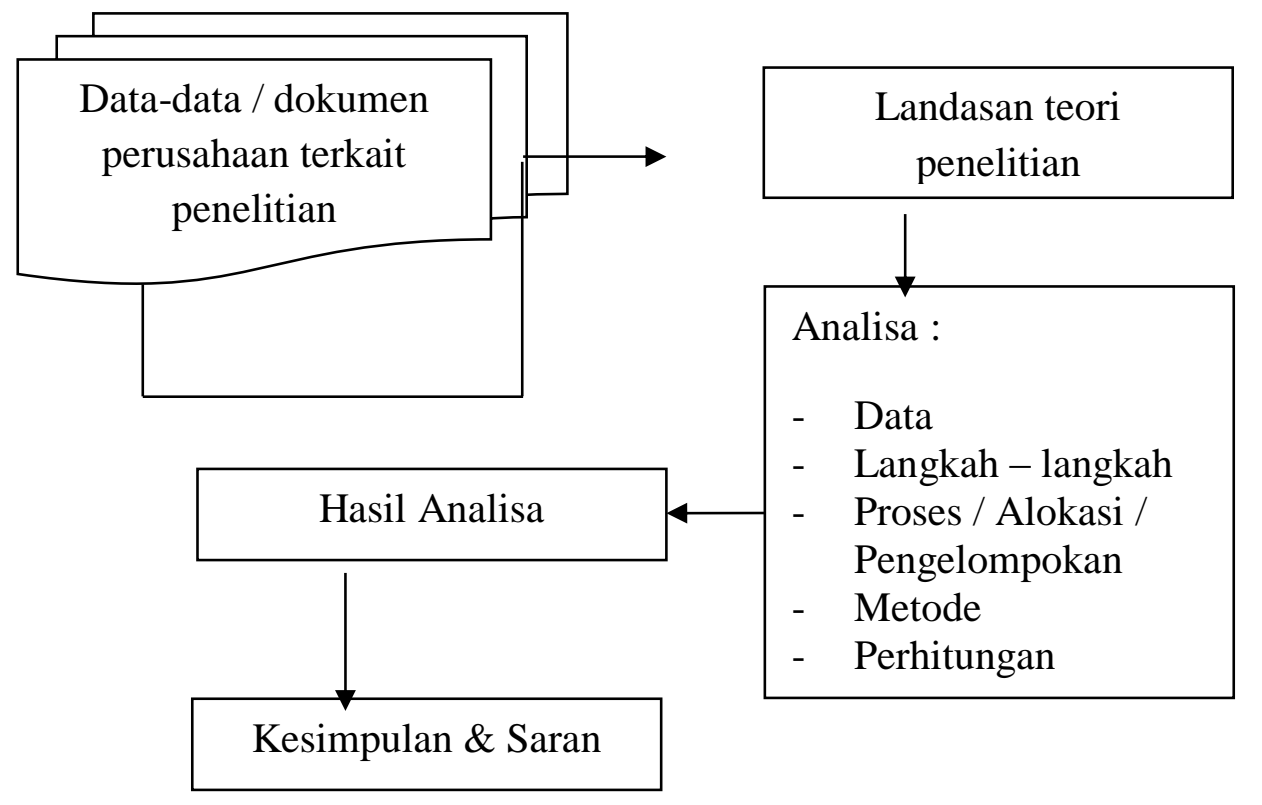

Gambar 3. Skema Analisa

Tabel 1. Laporan Data Penjualan Periode Oktober sampai dengan Desember 2016

\begin{tabular}{clrrr}
\hline Number & Description & \multicolumn{3}{c}{ Amount } \\
\cline { 3 - 5 } & & October & November & December \\
\hline 1 & ROM & 41.958 .600 & 371.439 .610 & 189.245 .760 \\
\hline 2 & SPLIT & 329.476 .300 & 495.397 .150 & 405.492 .800 \\
\hline & Total & 371.434 .900 & 866.836 .760 & 594.738 .560 \\
\hline
\end{tabular}

Data Laporan penjualan merupakan hasil rekapitulasi dari data hauling atas penjualan batu setiap periodenya yang kemudian total penjualan setiap periode digambarkan pada tabel tersebut diatas, yang akan ditunjukan tingkat penjulan dengan gambar kurva penjualan seperti ditunjukkan pada Gambar 4.

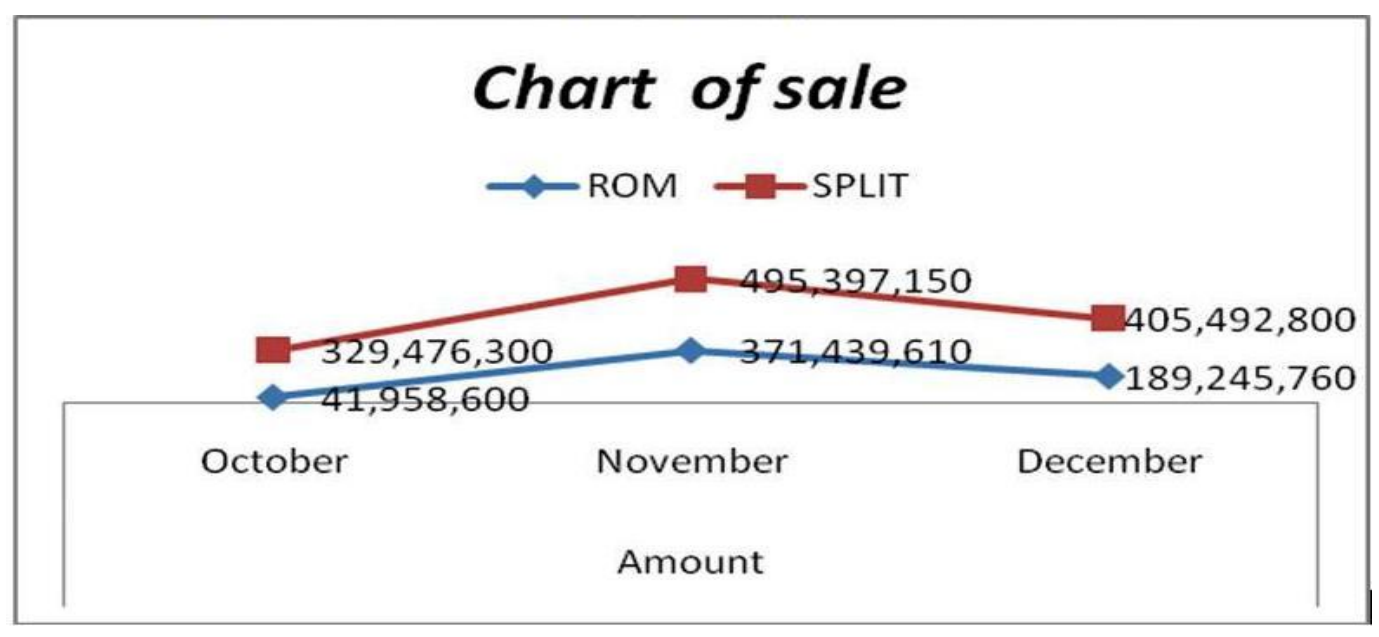

Gambar 4. Kurva PenjualanPeriode Oktober sampai dengan Desember 2016 
Berdasarkan kurva tersebut diatas dapat dijelaskan bahwa tingkat penjualan untuk SPLIT lebih tinggi dibandingkan ROM, dimana dinyatakan dengan penjualan tertinggi pada periode November 2016.

Tabel 2. Persediaan (inventory) Periode Oktober sampai dengan Desember 2016

\begin{tabular}{lrrr}
\hline \multicolumn{1}{c}{ Description } & \multicolumn{3}{c}{ Total $(C B M)$} \\
\cline { 2 - 4 } & October & November & December \\
\hline Production : & & & \\
a. ROM & 1,323 & 4,820 & 4,795 \\
b. SPLIT & 4,433 & 3,820 & 4,258 \\
\hline Total ROM Production & 5,756 & 8,640 & 9,053 \\
\hline
\end{tabular}

Persediaan adalah penjumlahan saldo awal persediaan dengan pembelian dikurangi saldo akhir , tetapi dalam penelitian ini nilai persediaan yang disajikan merupakan hasil dari aktivitas produksi sebelum dilakukan proses lanjutan untuk menghasilkan jenis SPLIT persediaan bisa dilihat dari pada hasil produksi.

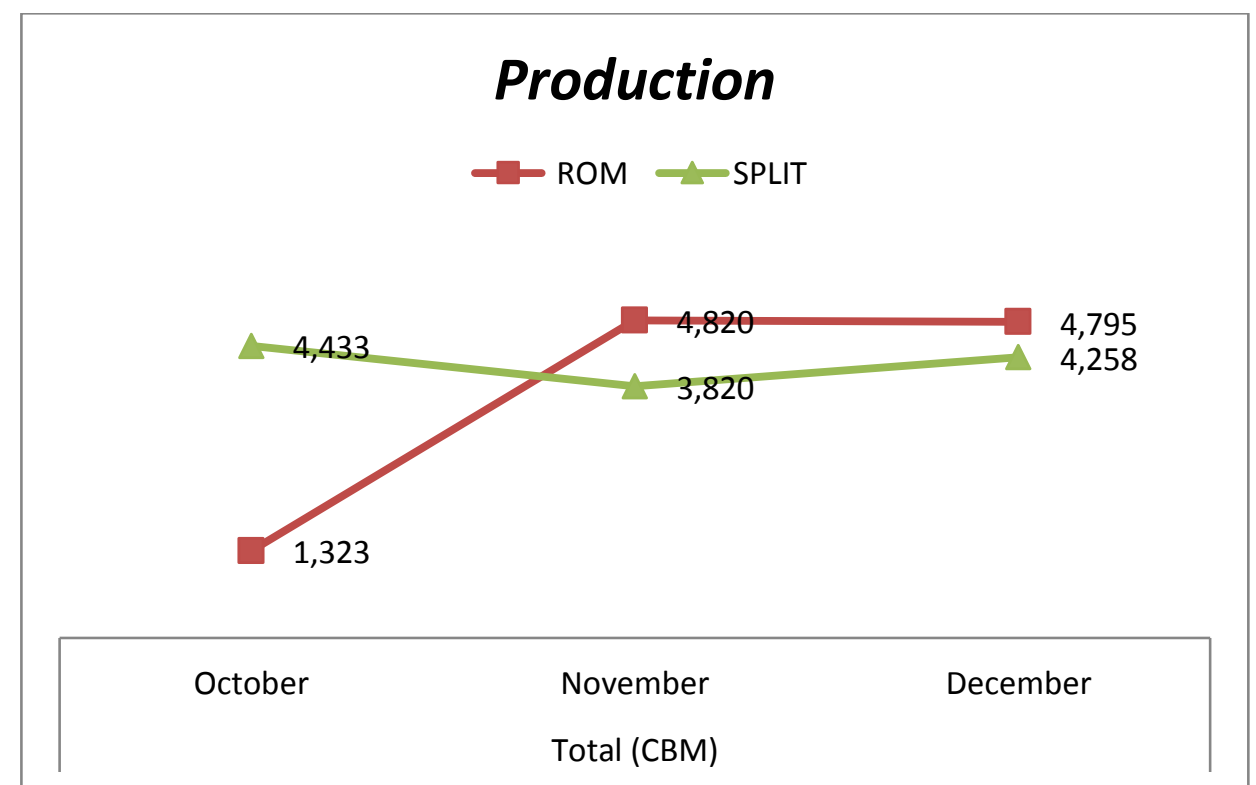

Gambar 5. Kurva Produksi Periode Oktober sampai dengan Desember 2016

Nilai pada kurva penjualan produksi menggambarkan grafik hasil penjualan produksi setiap jenis batu periode Oktober sampai dengan periode Desember 2016 , dimana pada tabel dan kurva dapat dilihat hasil produksi ROM bulan Oktober 5,756 cubic meters menghasilkan ROM 1,323 cubic meters dan SPLIT 4,433 cubic meters, hasil produksi ROM bulan November menghasilkan ROM 4,820 cubic meters dan SPLIT 3,820 cubic meters, serta hasil produksi ROM bulan Desember 9,052 cubic meters menghailkan ROM 4,795 cubic meters dan SPLIT 4,258 cubic meters. 
Tabel 3. Salary and Wages Periode Oktober sampai dengan Desember 2016

\begin{tabular}{|c|c|c|c|c|c|}
\hline \multirow[t]{2}{*}{ NO } & \multirow[t]{2}{*}{ TITLE } & \multirow[t]{2}{*}{ PERSON } & \multicolumn{3}{|c|}{ AMOUNT } \\
\hline & & & OCTOBER & NOVEMBER & DECEMBER \\
\hline \multicolumn{6}{|c|}{ RAW MATERIAL (ROM) } \\
\hline \multicolumn{6}{|c|}{ @ PIT (MINE BLOCK) } \\
\hline \multicolumn{6}{|c|}{ Panca } \\
\hline 1 & Operasional Lapangan & 1 & $10,000,000$ & $10,000,000$ & $10,000,000$ \\
\hline 2 & Op. BREAKER & 1 & $21,450,000$ & $15,575,000$ & $31,500,000$ \\
\hline 3 & Op. EXCAVATOR & 1 & $14,040,000$ & $10,230,000$ & $12,510,000$ \\
\hline 4 & Checker & 1 & $1,250,000$ & $1,250,000$ & $1,250,000$ \\
\hline & TOTAL & & $46,740,000$ & $37,055,000$ & $55,260,000$ \\
\hline \multicolumn{6}{|c|}{ HARMAK } \\
\hline 1 & Tim Harmak & 3 & $16,500,000$ & $16,500,000$ & $16,500,000$ \\
\hline 2 & Tim Lokal & 6 & $7,140,000$ & $8,640,000$ & $8,640,000$ \\
\hline 3 & Petugas Loket & 1 & $1,250,000$ & $1,250,000$ & $1,250,000$ \\
\hline 4 & Administration & 1 & $3,500,000$ & $3,500,000$ & $3,500,000$ \\
\hline 5 & Security & 4 & $6,000,000$ & $6,000,000$ & $6,000,000$ \\
\hline 6 & Car driver & 2 & $3,000,000$ & $3,000,000$ & $3,000,000$ \\
\hline 7 & Klebet Harian & 7 & $8,750,000$ & $8,750,000$ & $8,750,000$ \\
\hline & TOTAL & & $46,140,000$ & $47,640,000$ & $47,640,000$ \\
\hline & GRAND TOTAL & & $92,880,000$ & $84,695,000$ & $102,900,000$ \\
\hline \multicolumn{6}{|c|}{ SPLIT } \\
\hline \multicolumn{6}{|c|}{ @ STOCKPILE } \\
\hline 1 & Operator EXCAVATOR & 1 & $6,825,000$ & $5,250,000$ & $8,200,000$ \\
\hline 2 & Supervisor Crusher & 1 & $4,500,000$ & $4,500,000$ & $4,500,000$ \\
\hline 3 & Checker & 2 & $3,300,000$ & $3,300,000$ & $3,300,000$ \\
\hline 4 & Truck driver & 1 & $1,800,000$ & $1,800,000$ & $1,800,000$ \\
\hline & TOTAL & & $16,425,000$ & $14,850,000$ & $17,800,000$ \\
\hline
\end{tabular}

Tabel 3 menunjukkan gaji dan upah yang dikeluarkan perusahaan dari bulan Oktober hingga Desember 2016. Upah tenaga kerja langsung pada penelitian ini merupakan upah tenaga kerja yang berhubungan dengan lokasi tambang dan stockpile dimana terjadinya proses produksi berhubungan langsung dengan proses produksi dan prosesnya.

Untuk memperjelas sistem kerja karyawan di PT. Harmark Indonesia Yogyakarta maka perlu digambarkan diagram alur fungsi-fungsi dari masing-masing jabatan dan bagaimana mereka berinteraksi satu sama lain, seperti ditunjukkan pada Gambar 6. Jabatan yang dijabarkan pada diagram alur tersebut meliputi operator, pengawas atau checker, supir dump truck, supervisor pengawas, dan site manager. Kegiatan diawali dari rencana kerja yang dibuat oleh site manager kemudian diteruskan ke jabatan-jataban terkait yang ada dibawahnya, hingga proses produksi bisa berjalan dan site manager mendapatkan laporan hasil produksi bahan baku. 


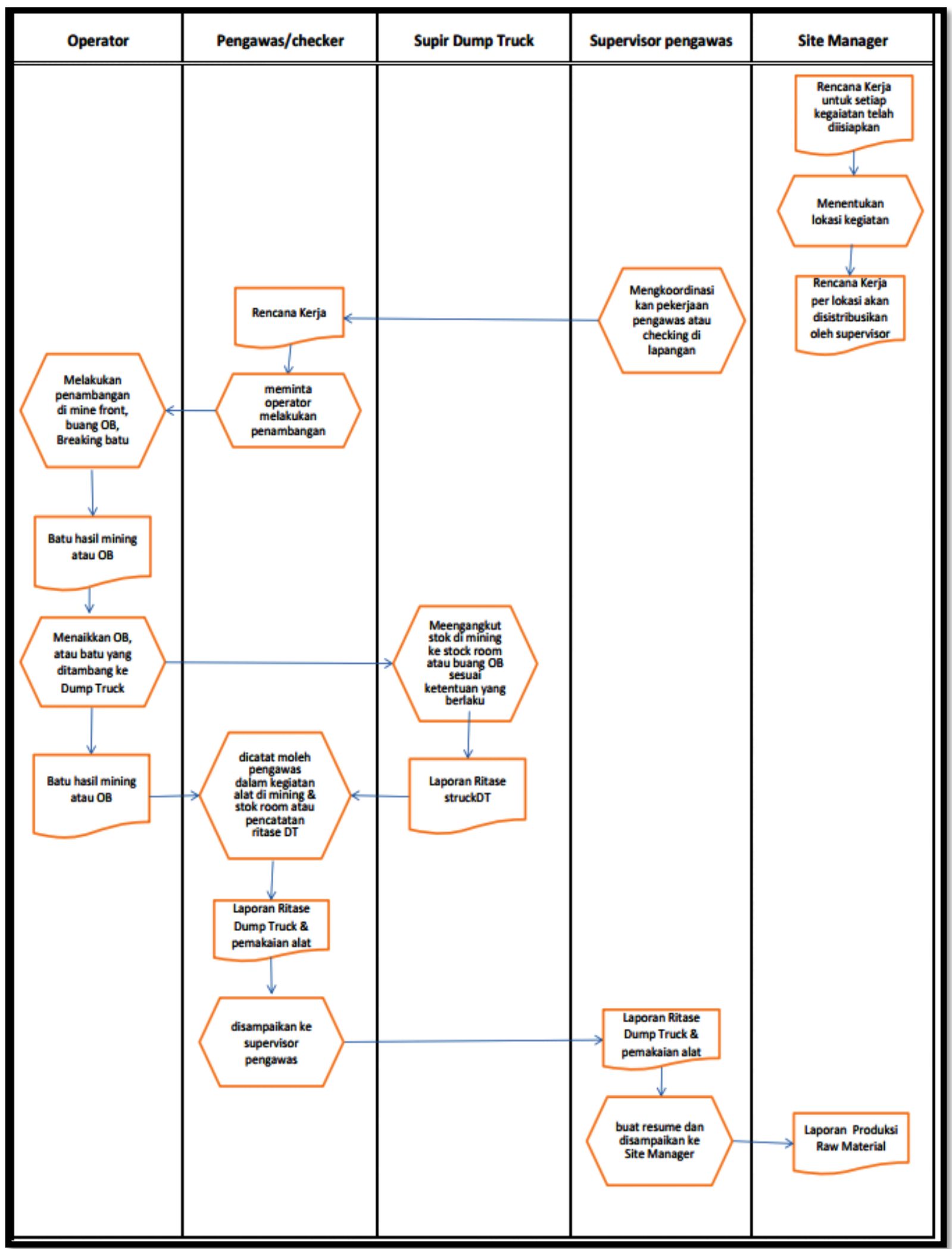

Gambar 6. Chart of diagram mining to employee functions Periode Oktober s.d Desember 2016 
Tabel 4. Heavy equipment and fuel Periode Oktober sampai dengan Desember 2016

\begin{tabular}{|c|c|c|c|c|c|}
\hline \multirow[t]{2}{*}{ NO } & \multirow[t]{2}{*}{ TYPE OF EQUIPMENT } & \multirow[t]{2}{*}{ UNIT } & \multicolumn{3}{|c|}{ AMOUNT } \\
\hline & & & OCTOBER & NOVEMBER & DECEMBER \\
\hline \multicolumn{6}{|c|}{ RAW MATERIAL (ROM) } \\
\hline \multicolumn{6}{|c|}{$@$ PIT (MINE BLOCK) } \\
\hline \multicolumn{6}{|c|}{ FUEL } \\
\hline 1 & EXCAVATOR & 1 & $21,000,000$ & $25,970,000$ & $23,380,000$ \\
\hline 2 & BREAKER & 1 & $25,200,000$ & $27,370,000$ & $39,340,000$ \\
\hline 3 & OLI & & 0 & 0 & 0 \\
\hline \multicolumn{6}{|c|}{ RENT/HEAVY EQUIPMENT } \\
\hline 4 & EXCAVATOR & 1 & $22,350,000$ & $21,750,000$ & $24,750,000$ \\
\hline \multirow[t]{2}{*}{5} & BREAKER & 1 & $39,325,000$ & $33,275,000$ & $72,325,000$ \\
\hline & & TOTAL & $107,875,000$ & $108,365,000$ & $159,795,000$ \\
\hline \multicolumn{6}{|c|}{ SPLIT } \\
\hline \multicolumn{6}{|c|}{ @ STOCKPILE } \\
\hline \multicolumn{6}{|c|}{ FUEL } \\
\hline 1 & EXCAVATOR & 1 & $18,550,000$ & $17,710,000$ & $27,090,000$ \\
\hline 2 & GENSET $500 \mathrm{KVA}$ & 1 & $43,400,000$ & $38,500,000$ & $39,326,000$ \\
\hline 3 & DUMP TRUCK & 1 & $1,560,000$ & $1,560,000$ & $1,560,000$ \\
\hline \multicolumn{6}{|c|}{ RENT/HEAVY EQUIPMENT } \\
\hline 4 & EXCAVATOR & 1 & $21,500,000$ & $28,000,000$ & $28,000,000$ \\
\hline 5 & GENSET $500 \mathrm{KVA}$ & 1 & $30,000,000$ & $30,000,000$ & $30,000,000$ \\
\hline 6 & LEASING DUMP & 1 & $7,600,400$ & $7,600,400$ & $7,600,400$ \\
\hline 7 & RENT DUMP TRUCK & 2 & $27,000,000$ & $27,000,000$ & $18,000,000$ \\
\hline 8 & RENT STOCKPILE & & 750,000 & $1,666,667$ & $1,750,000$ \\
\hline & & $101 \mathrm{AL}$ & $150,360,400$ & $152,037,067$ & $153,326,400$ \\
\hline
\end{tabular}

Penggunaan alat berat dan solar pada penelitian ini merupakan pemakaian alat berat dan solar atas proses produksi yang telah di klasifikasi berdasarkan pengunaan yang diperlukan untuk proses produksi ROM dan SPLIT.

Tabel 5. Biaya Administrasi, Umum dan Biaya Overhead Lainnya Produksi Periode Oktober sampai dengan Desember 2016

\begin{tabular}{|c|c|c|c|}
\hline KETERANGAN & OKTOBER & NOVEMBER & DESEMBER \\
\hline Biaya Perijinan & - & - & $6,500,000$ \\
\hline Biaya Royalti & $37,444,000$ & $55,522,000$ & $59,892,000$ \\
\hline Biaya Retribusi & - & $8,810,000$ & $13,696,500$ \\
\hline Biaya Pajak Galian C & $26,862,000$ & $94,146,000$ & $101,556,000$ \\
\hline Biaya Penyiraman & $1,460,000$ & - & - \\
\hline Biaya Perbaikan \& Pemeliharaan Jalan & $39,610,000$ & $48,620,000$ & $141,362,800$ \\
\hline Biaya Perbaikan \& Pemeliharaan & $12,003,000$ & $15,565,000$ & $12,866,500$ \\
\hline Biaya Kesehatan & 331,000 & 125,000 & 35,000 \\
\hline Biaya Housing & 600,000 & 300,000 & 550,000 \\
\hline Biaya ATK & $1,031,800$ & 321,000 & $1,922,000$ \\
\hline Biaya Perlengkapan Penunjang & $1,990,000$ & $6,036,200$ & $3,358,500$ \\
\hline Biaya Dapur & $4,215,900$ & 161,500 & - \\
\hline Biaya Sumbangan dan $C S R$ & 200,000 & $14,705,000$ & $1,000,000$ \\
\hline Biaya Konsumsi & $7,830,000$ & $23,690,250$ & $51,057,750$ \\
\hline Biaya Transportasi & $3,525,200$ & $9,538,920$ & $7,526,300$ \\
\hline Biaya Utilities - PAM & - & 754,000 & - \\
\hline Biaya Utilities - Telepon & 390,000 & 666,500 & 322,000 \\
\hline Biaya Utilities - Listrik & 87,400 & 76,000 & 72,000 \\
\hline Biaya Administrasi Bank & 105,778 & 165,701 & 84,662 \\
\hline Biaya Lain-lain & 300,000 & - & - \\
\hline Total & $137,986,078$ & $279,203,071$ & $401,802.012$ \\
\hline
\end{tabular}


Perincian biaya - biaya yang dikeluarkan atas biaya administrasi, umum dan overhead lainnya pada penelitian ini merupakan biaya-biaya yang dikeluarkan untuk produksi ROM dan SPLIT. Karena proses split dimulai dengan menghasilkan ROM , proses produksi SPLIT ini digambarkan pada Gambar 7.

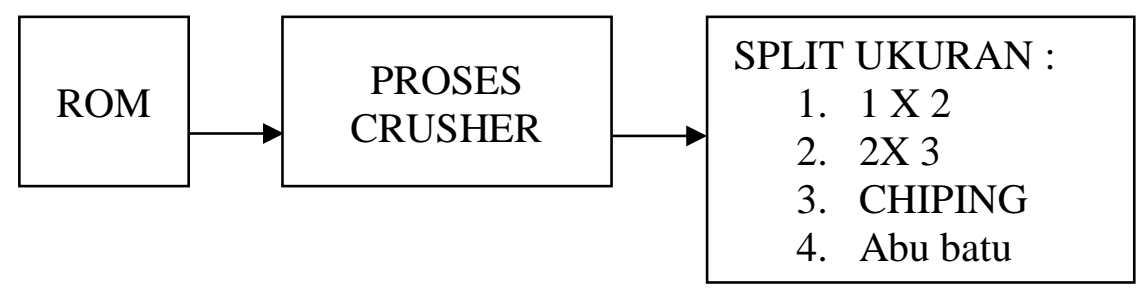

Gambar 7. Proses Produksi

Tabel 6. Biaya Sparepart and pemeliharaan crusher Periode Oktober sampai dengan Desember 2016

\begin{tabular}{cccc} 
KETERANGAN & OKTOBER & NOVEMBER & DESEMBER \\
Crusher sparepart and maintanance & $26,030,576$ & $22,328,280$ & $25,000,040$ \\
\hline
\end{tabular}

Tabel 7. Harga Pokok Penjualan Periode Oktober sampai dengan Desember 2016

\begin{tabular}{|c|c|c|c|}
\hline KETERANGAN & OKTOBER & NOVEMBER & DESEMBER \\
\hline TOTAL PRODUKSI & 5,756 & 8,640 & 9,053 \\
\hline \multicolumn{4}{|l|}{$\underline{\mathrm{ROM}}$} \\
\hline Produksi & 1,323 & 4,820 & 4,795 \\
\hline Tenaga Kerja (Gaji dan Upah/ Salary \& Wages) & $92,880,000$ & $84,695,000$ & $102,900,000$ \\
\hline Alat Berat dan Solar & $107,875,000$ & $108,365,000$ & $159,795,000$ \\
\hline $\begin{array}{l}\text { Biaya Administrasi, Umum dan Biaya Overhead } \\
\text { Lainnya }\end{array}$ & $\underline{137,986,078}$ & $\underline{279,203,070}$ & $\underline{401,802,012}$ \\
\hline Total Biaya & $338,741,078$ & $472,263,070$ & $664,497,012$ \\
\hline COGS TOTAL PRODUKSI ROM & 58,850 & 54,660 & 73,401 \\
\hline \multicolumn{4}{|l|}{ SPLIT } \\
\hline Produksi & 4,433 & 3,820 & 4,258 \\
\hline Tenaga Kerja (Gaji dan Upah/ Salary \& Wages) & $16,425,000$ & $14,850,000$ & $17,800,000$ \\
\hline Alat Berat dan Solar & $150,360,400$ & $152,037,067$ & $153,326,400$ \\
\hline Biaya Sparepart and pemeliharaan crusher & $\underline{26,030,576}$ & $\underline{22,328,280}$ & $\underline{25,000,040}$ \\
\hline Total Biaya & $192,815,976$ & $189,215,347$ & $196,126,440$ \\
\hline Harga pokok proses crusher $R O M$ & 43,496 & 49,533 & 46,061 \\
\hline COGS TOTAL PRODUKSI SPLIT & 102,346 & 104,193 & 119,461 \\
\hline
\end{tabular}

Tabel 8. Harga pokok penjualan (cost of good sold)

\begin{tabular}{lrrr}
\hline \multicolumn{1}{c}{ KETERANGAN } & OKTOBER & \multicolumn{1}{c}{ NOVEMBER } & \multicolumn{1}{c}{ DESEMBER } \\
\hline Harga pokok penjualan & & & \\
\hline - ROM & 58,850 & 54,660 & 73,401 \\
\hline - SPLIT & 102,346 & 104,193 & 119,461 \\
\hline
\end{tabular}




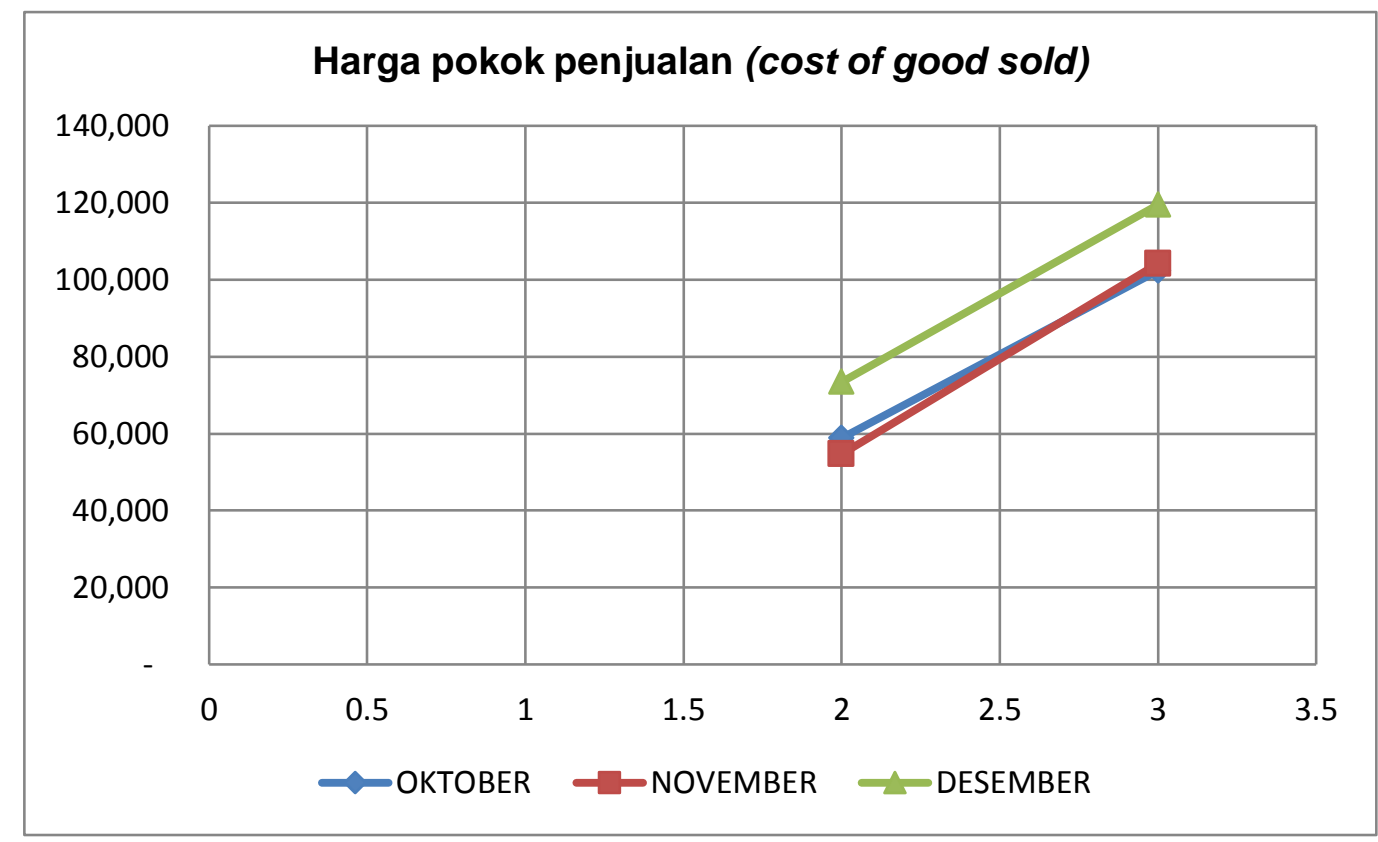

Gambar 8. Kurva harga pokok penjualan (cost of good sold)

Analisa Harga pokok penjualan yang digunakan dalam penentuan harga jual batu andesit pada PT. Harmak Indonesia, Yogyakarta untuk jenis ROM dan SPLIT apabila perusahaan menentukan margin keuntungan maka perhitungan seperti ditunjukkan pada Tabel 9.

Tabel 9. Perhitungan Harga Pokok Penjualan Batu Andesit pada PT. Harmark Indonesia

\begin{tabular}{|c|c|c|c|c|}
\hline KETERANGAN & MARGIN & OKTOBER & NOVEMBER & DESEMBER \\
\hline - ROM & & 58,850 & 54,660 & 73,401 \\
\hline & $10 \%$ & 5,885 & 5,466 & 7,340 \\
\hline & $20 \%$ & 11,770 & 10,932 & 14,680 \\
\hline & $30 \%$ & 17,655 & 16,398 & 22,020 \\
\hline - SPLIT & & 102,346 & 104,193 & 119,461 \\
\hline & $10 \%$ & 10,235 & 10,419 & 11,946 \\
\hline & $20 \%$ & 20,469 & 20,839 & 23,892 \\
\hline & $30 \%$ & 30,704 & 31,258 & 35,838 \\
\hline
\end{tabular}

Harga pokok penjualan (Cost Good Of Sold) dilakukan untuk memproyeksikan tingkat kemajuan perusahaan yang diharapkan dimasa mendatang, dimana juga sumber data untuk mengukur biaya, merencanakan dan mengendalikan serta untuk menganalisa biaya. Biaya yang terkait langusng dalam produksi dan penjualan batu andesit di lokasi pertambangan. Harga pokok penjualan (Cost Good Of Sold) dalam (istilah yang dipakai IAI) harga pokok penjualan (Cost Good Of Sold) adalah segala cost yang timbul dalam rangka membuat suatu produk menjadi siap untuk dijual atau dengan kalimat lain, Harga Pokok penjualan adalah cost yang terlibat dalam proses pembuatan barang atau yang bisa dihubungkan langsung dengan proses yang membawa barang dagangan siap untuk dijual. Penetapan Harga pokok penjualan (Cost Of Good Sold) pada PT. Harmak Indonesia Yogyakarta yang selama ini berjalan masih ada alokasi biaya yang mengalami kerancuan karena tidak dipertegas dengan penjelasan pengeluaran biaya 
secara spesifik sehingga mengalami kesulitan dalam penentuan biaya, sehingga ada beberapa biaya yang akhirnya berupa estimasi dan penggabungan secara keseluruhan.

Hasil analisis penetapan harga pokok penjualan (Cost Of Good Sold) yang seharusnya pada PT. Harmak Indonesia Yogyakarta pada periode Oktober sampai dengan Desember 2016 dalam penelitian ini telah dibuat alokasi sesuai dengan seharusnya yang mana menghitung semua biaya-biaya yang dikeluarkan perusahaan baik biaya - biaya produksi maupun non produksi. Dari penelitian yang dilakukan maka data dilihat hasil penentuan harga pokok penjualan lebih tinggi daripada harga pokok penjualan yang dihitung oleh perusahaan, dengan terlihatnya perbedaan hasil penelitian perbedaan perhitungan harga pokok penjualan terjadi karena adanya kerancuan alokasi biaya dan biaya - biaya yang tidak dimasukan kedalam pehitungan harga pokok penjualan (cost of good sold) seperti pemeliharaan jalan untuk proses hauling, biaya CSR.

Tabel 10. Result Cost Of Good Sold Periode Oktober sampai dengan Desember 2016

\begin{tabular}{lccrrrr}
\hline & \multicolumn{2}{c}{ OCTOBER } & \multicolumn{2}{c}{ NOVEMBER } & \multicolumn{2}{c}{ DECEMBER } \\
\hline & DATA & RESULT & DATA & RESULT & \multicolumn{1}{c}{ DATA } & \multicolumn{1}{c}{ RESULT } \\
\hline - ROM & 58,249 & 58,850 & 48,937 & 54,660 & 65,855 & 73,401 \\
\hline - SPLIT & 101,744 & 102,346 & 98,698 & 104,193 & 111,921 & 119,461 \\
\hline
\end{tabular}

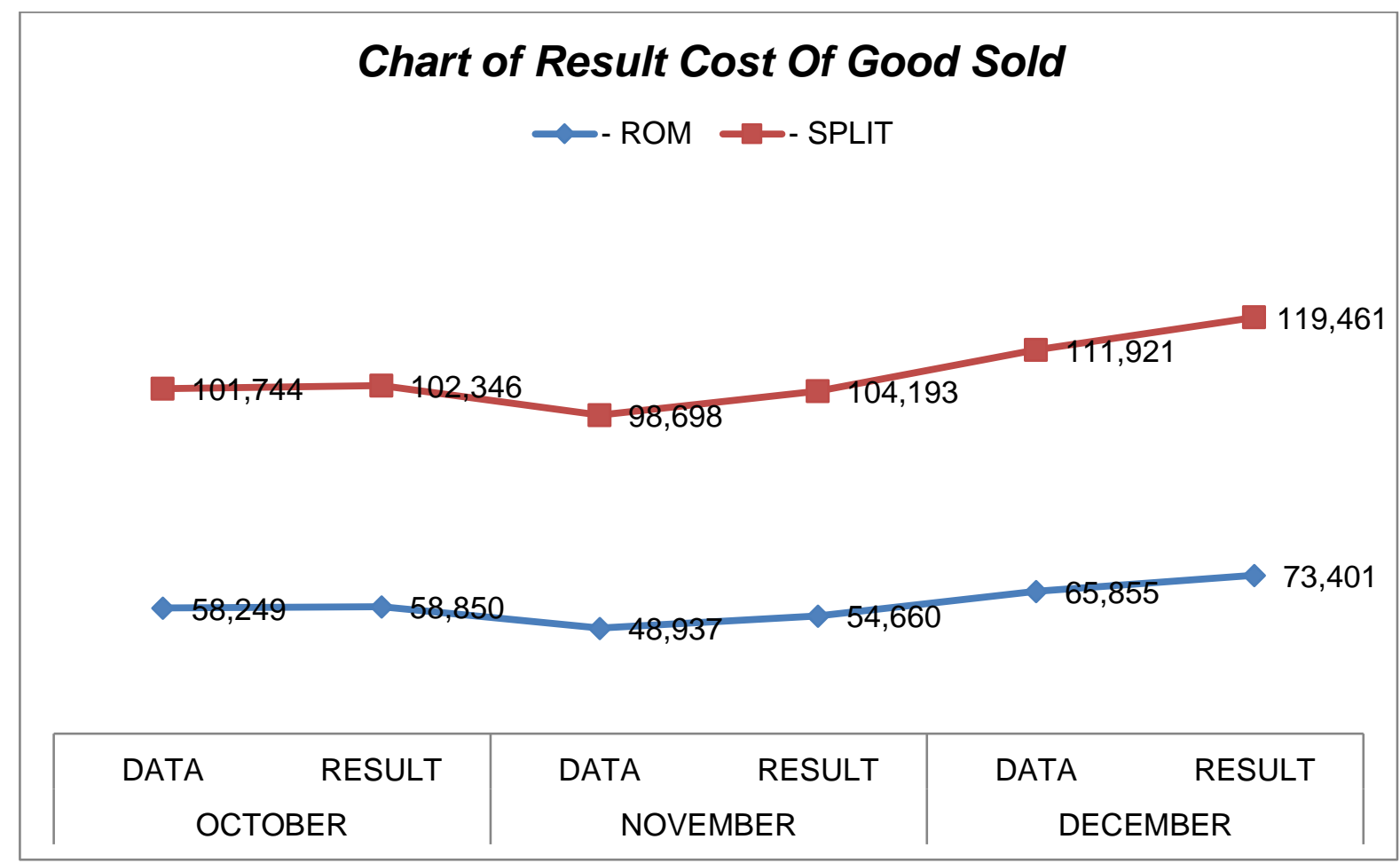

Gambar 9. Kurva Result of Cost Of Good Sold

\section{Kesimpulan}

Berdasarkan hasil penelitian dan pembahasan yang telah disajikan, maka dapat disimpulkan sebagai berikut :

1. Penetapan harga Harga pokok penjualan (Cost Of Good Sold) yang selama ini berjalan masih ada alokasi biaya yang mengalami kerancuan karena tidak dipertegas dengan penjelasan 
pengeluaran biaya secara spesifik sehingga mengalami kesulitan dalam penentuan biaya, sehingga ada beberapa biaya yang akhirnya berupa estimasi dan penggabungan secara keseluruhan, seperti biaya perbaikan aau pemeliharaan jalan dan Biaya Corporate Social Reponsibility (CSR) dalam penetapan harga pokok penjualan, sehingga dapat mempengaruhi perhitungan dalam penentuan harga pokok penjualan.

2. Penetapan Harga pokok penjualan (Cost Of Good Sold) yang seharusnya dalam perhitungan penetapan penentuan harga pokok penjualan selain biaya-biaya, jumlah persediaan dari jenis batu andesit juga bagian dari penentu karena merupakan pembagi dalam menentukan hasil. Dengan adanya hal tersebut diatas maka perhitungan harga pokok penjualan kurang tepat dan mempengaruhi nilai penetapan harga pokok penjualan yang cukup signifikan, seperti : Cost of good sold ROM periode Oktober data dengan hasil penelitian mengalami selisih Rp 601.00, November Rp 5,723.00, Desember Rp 7,546.00 sedangkan Cost of good sold SPLIT periode Oktober data dengan hasil penelitian mengalami selisih Rp 602.00 , November Rp 5,495.00, Desember Rp 7,540.00

3. Penentuan harga jual batu andesit untuk jenis ROM dan SPLIT oleh perusahaan harus memiliki ketetapan berapa nilai keuntungan atau margin yang ingin diperoleh sehingga penentuan harga jual haruslah diatas dari harga pokok penjualan dengan ditambahkan dengan margin keuntungan yang diharapkan, seperti ketentuan margin keuntungan $10 \%$, $20 \%, 30 \%$ dan seterusnya sesuai dengan yang diinginkan diatas (>) harga pokok penjualan ROM dan SPLIT.

Hasil dari penelitian ini diharapkan membawa manfaat bagi banyak pihak, terutama bagi pihak investor, perusahaan, dan penelitian selanjutnya, seperti dijabarkan sebagai berikut :

1 Bagi Perusahaan perlu dilakukan penelitian lanjutan tentang detail persediaan atas produksi, alokasi biaya yang dapat menyebabkan kerancuan, double pencatatan dan adanya biaya yang tidak terhitung dalam pengeluaran biaya-biaya yang berhubungan dengan harga pokok penjualan, sehingga dapat menentukan harga jual yang dapat bersaing untuk meningkatkan minat pembeli terhadap produk yang dihasilkan.

2 Bagi Investor sebelum memutuskan untuk menanamkan modal selain melihat dari prospek perusahaan kedepan, hendaknya melihat bagaimana penetapan harga pokok penjualan atas produk sebelum menganalisa laporan keuangan sehingga dapat memprediksi tingkat penghasilan dan laba yang diinginkan.

3 Bagi Peneliti Selanjutnya dapat memberikan infomasi dan data-data untuk melakukan penelitian lanjutan atau penelitian baru yang memiliki hubungan informasi dengan analisa pada penelitian ini

\section{DAFTAR PUSTAKA}

Ainun Na'im, 1992, Akuntansi Keuangan II, BPFE, Yogyakarta.

Hansen dan Mowen, 2007, Akuntansi Manajemen, Terjemahan HermawanJilid 1,

Penerbit Erlangga, Jakarta.

Jogiyanto,2003, Metodologi Penelitian Bisnis, BPFE, Yogyakarta.

John Downews and Jordan Elliot Goodman,1999, Kamus Istilah Keuangan dan investasi,PT.Elex Media Komputindo, Jakarta.

Mulyadi, 2009, Akuntansi Biaya, Penerbit Aditya Media.Yogyakarta

Mulyadi. 2010. Akuntansi Biaya, Edisi 5, Cetakan ke-7. Unit Penerbit dan

Percetakan YKPN, Yogyakarta.

Niswonger, C.R., Fess, P. E., \& Warrem, CS (1992). Prinsip-prinsip Akuntansi

(16th ed). Jakarta : Erlangga

Reymon, 2009, Analisa Penerapan Harga Jual Dengan Metode Variable Costing 
pada PT. Massindo Sinar Pratama Manado,Skripsi (tidak dipublikasikan) pada Fakultas \& Bisnis Jurusan Akuntansi Universitas Samratulangi Manado. Hal 50-52

Soemarso. 2010. Akuntansi Suatu Pengantar, Edisi 5 Revisi. Jakarta:

Salemba Empat.

Supriyono, R. A, 2010, Akuntansi Biaya: Pengumpulan Biaya dan Penentuan

Harga Pokok, Edisi ke - 14, enerbit BPFE-Yogyakarta.

Suwardjono,2010, Dasar-Dasar Akuntansi, Edisi Keenam, Penerbit STIE YKPN,

Yogyakarta.

Suwardjono. 2010. Akuntansi Pengantar Bagian I, Edisi ke-3, Cetakan ke2.

Yogyakarta: BPFE.

Yusuf,Haryono AL, 2007, Dasar-dasar Akuntansi 2, Jilid 2 Edisi ketujuh,

Yogyakarta, STIE YKPN.

Triogo Utomo dan Christiono Utomo, 2014, Penetapan harga Pokok Penjualan

Berdasarkan Alokasi Biaya Terhadap Posisi Rumah pada Perumahan Green Park Residence

Sampang. Jurusan Teknik Sipil, Fakultas Teknik Sipil \& Perencanaan, Institusi Teknologi

Sepuluh Nopember (ITS), Jurnal Teknik POMITS

Van Derbeck, Edward J. 2005. Principles of Cost Accounting, Edisi 13.

South- Western Publishing. Cincinnati, Ohio, USA.

http://ejournal.unsrat.ac.id/index.php/emba/article/view/2060

http://ejournal.unsrat.ac.id/index.php/emba/article/view/1638/1309

http://www.ejurnal.its.ac.id/index.php/teknik/article/view/7018/1948

http://ejournal.unsrat.ac.id/index.php/emba/article/view/5898/5430

http://homkreasi.blogspot.co.id/2013/08/rumus-menghitung-harga-pokok-penjualan.html

https://scholar.google.co.id/scholar?q=harga+pokok+penjualan+\&btnG=\&hl=id\&as_sdt=0\%2

C5

http://www.pengertianpakar.com/2015/06/pengertian-metode-penelitian-jenis-dan-

contohnya.html

https://id.wikipedia.org/wiki/Andesit 